\title{
Chromatin dynamics and in vitro biomarkers in laminopathies: an overview
}

\author{
Giovanna Lattanzi \\ From 1st French-Italian meeting on laminopathies and other nuclear envelope-related diseases \\ Marseille, France. 15-16 January 2015
}

Chromatin regulation in eukaryotes occurs through complex and interconnected mechanisms that ensure heterochromatin maintenance and compartmentalization of chromosome domains, genome stability, chromatin conformational changes before and after mitosis, gene silencing and transcriptional activation and chromatin remodeling at specific promoters. We refer to these events as a whole using the term "chromatin dynamics." Chromatin dynamics involves a number of protein families including epigenetic enzymes, DNA repair factors, heterochromatin proteins, transcription factors and transcriptional regulators. Although lamins have been involved in almost all the processes that regulate chromatin dynamics [1], three main functions link lamins to chromatin regulation: recruitment of the DNA damage response proteins [2], transcription factor binding [3,4] and modulation and maintenance of heterochromatin domains [5]. Our preliminary data have shown that lamin $\mathrm{A} / \mathrm{C}$ plays a major role in anchorage of epigenetic enzymes in nuclei and loss of lamin $\mathrm{A} / \mathrm{C}$ - histone deacetylase (HDAC) binding, as occurs in Hutchinson-Gilford progeria (HGPS) cells, affects enzyme activity and histone acetylation. These results may explain our previously published data [6] showing that the heterochromatin defects of HGPS cells can be rescued by combined inhibition of prelamin A farnesylation and HDAC activity and pave the way to new therapeutic perspectives. Moreover, altered lamin A/C-HDAC interaction and histone acetylation patterns can be explored as potential biomarkers for laminopathies.

Published: 11 November 2015

Correspondence: giovanna.lattanzi@cnr.it

CNR Institute for Molecular Genetics, Unit of Bologna and Rizzoli Orthopedic Institute, Laboratory of Musculoskeletal Cell Biology, Bologna, Italy

\section{References}

1. Camozzi D, Capanni C, Cenni V, Mattioli E, Columbaro M, Squarzoni S, et al: Diverse lamin-dependent mechanisms interact to control chromatin dynamics. Focus on laminopathies. Nucleus 2014, 5(5):427-40.

2. Lattanzi G, Ortolani M, Columbaro M, Prencipe S, Mattioli E, Lanzarini C, et al: Lamins are rapamycin targets that impact human longevity: a study in centenarians. Journal of cell science 2014, 127(Pt 1):147-57.

3. Capanni C, Mattioli E, Columbaro M, Lucarelli E, Parnaik VK, Novelli G, et al: Altered pre-lamin A processing is a common mechanism leading to lipodystrophy. Human molecular genetics 2005, 14(11):1489-502.

4. Columbaro M, Mattioli E, Maraldi NM, Ortolani M, Gasparini L, D'Apice MR, et al: Oct-1 recruitment to the nuclear envelope in adult-onset autosomal dominant leukodystrophy. Biochimica et biophysica acta 2013, 1832(3):411-20.

5. Lattanzi G, Columbaro M, Mattioli E, Cenni V, Camozzi D, Wehnert M, et al: Pre-Lamin A processing is linked to heterochromatin organization. Journal of cellular biochemistry 2007, 102(5):1149-59.

6. Columbaro M, Capanni C, Mattioli E, Novelli G, Parnaik VK, Squarzoni S, et al: Rescue of heterochromatin organization in Hutchinson-Gilford progeria by drug treatment. Cellular and molecular life sciences: CMLS 2005, 62(22):2669-78.

\section{doi:10.1186/1750-1172-10-S2-O12}

Cite this article as: Lattanzi: Chromatin dynamics and in vitro

biomarkers in laminopathies: an overview. Orphanet Journal of Rare

Diseases 2015 10(Suppl 2):012.
() Biomed Central

(c) 2015 Lattanzi This is an Open Access article distributed under the terms of the Creative Commons Attribution License (http://

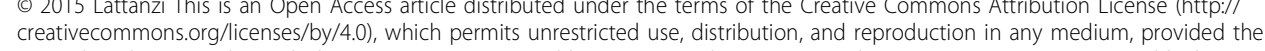
original work is properly cited. The Creative Commons Public Domain Dedication waiver (http://creativecommons.org/publicdomain/ zero/1.0/) applies to the data made available in this article, unless otherwise stated.
Submit your next manuscript to BioMed Central and take full advantage of:

- Convenient online submission

- Thorough peer review

- No space constraints or color figure charges

- Immediate publication on acceptance

- Inclusion in PubMed, CAS, Scopus and Google Scholar

- Research which is freely available for redistribution

Submit your manuscript at

cript at

C Biomed Central 